\title{
Satisfaction of Academic Youth with the Way Their Family of Origin Functions: Conditions and Determinants
}

\begin{abstract}
The family is the environment that leaves its mark and imprint the most in the structure of the human identity. This is because of both the broadly reaching and permanent character of impacts. Every family creates and regulates its particular familial identity. It can be seen as a kind of azimuth of feeling of being a member of an important, specific family community, despite the changes that are taking place in and around us. The text presents the results of research conducted in the group of academic youth regarding the level of the sense of satisfaction with the functioning of their family of origin and an attempt to capture the determinants of them. There are significant differences in the range of predictors building models for the whole group, compared to models built separately for the group of males and females. This indicates a high level of diversity in the perception of the family of origin system among the surveyed students. Analyses of the presented models show the image of academic youth who, in their life orientations, highly values the family as the basic reference point in the construction of their own identity. There is a visible focus on the community nature of its functioning, the quality of the relations of individual members of the system and the possibility of participating in the rules and rules developed in the family. The family identity that develops with said rules is a kind of negotiated creation of the family traditions recognized by them, with simultaneous outlined tendencies of deconstruction of the existing model ways of capturing the family structure, in favor of seeking a different view, which is a kind of adaptation of the system to dynamically changing socio-cultural conditions.
\end{abstract}

\section{Keywords:}

family system, family identity, identification, youth, level of satisfaction

Faculty of Education, University of Białystok, Poland.

E-MAIL: t.bajkowski@uwb.edu.pl ORCID: 0000-0003-4931-8637 


\section{INTRODUCTION}

Family is the environment that leaves the largest imprint on the structure of one's identity. This is because of both the broadly reaching and permanent character of impacts. The level of the impact of these factors is determined by developmental characteristics of family life cycle, the quality of the relations within a family and the specificity of intra-generational transmission in this defined space of interaction. Numerous studies on the development of the identity of a young person (Papini, 1994; Rostowski, 2003, pp. 19-31; Rostowski, 2005, pp. 13-21) prove that its proper course is determined by the appropriate participation of the family in this process, based on the sensitivity, support and flexibility of all its members, in response to the natural process of social exploration.

Every family creates and regulates its particular familial identity. I assumed that family identity involves certain azimuths of the feeling of being Someone belonging to an important family community, despite changes taking place in us and around us. I assume that each element of family system may help other elements feed on common resources and on the dynamics of relation occurring within its space. For the sake of optimizing the process of constructing one's own identity, it is important for him to achieve a sense of family coherence (Antonovsky, 1995, p. 34). This may be treated as the psychosocial capital of an individual, a sort of model of perceiving family in cognitive, emotional and instrumental aspect (Werner, 2013, pp. 73-83). This helps to answer the most important existential questions concerning: the place of an individual in a family, specificity of division of roles in family, dominating emotional states of its members, family capacity of confronting developmental tasks and internal and external crises, etc. In the identity structure, the sense of family coherence is responsible for the development of both the element of identification with the family and giving it a certain meaning (valence).

\section{THE CONCEPT OF OWN RESEARCH}

Analyzing the family system understood as a set of elements connected with each other by interactions and dependencies - constituting a single entity, able to function according to certain rules (Barbaro, 1999) - I assumed that both its structure and the essence of functioning should be examined. My research aimed at showing some common, but also specific and unique features of the family system of the studied academic youth. 
Selecting academic youth as research group was dictated by the uniqueness of this stage of life of a young person, who is somewhat suspended between his family of origin and creating a visions of his own family system. In this case, familial identity has a trajectile structure, which constitutes a certain bridge on the temporal axis. It concerns both the past, the current perception of the system, and the prospects for the future, anticipating the upcoming family constructs. I am certain that young people, due to their confrontational nature of experiencing identity dilemmas, are capable of re-defining the idea of family functioning, creatively transforming the manner in which its structure is formed, and internally renegotiating the rules and goals that form it.

The aim of this work is to diagnose family systems of academic youth, to learn its structure, specifics of interactions, sources affecting life attitudes of examined people, personal and social role models important for examined students, family profiles and identification of main determinants of the observed families of origin. The analysis of the research results was to be used to construct conclusions for the practice, diagnostic and methodological nature, which could be useful in creating specific procedures to identify the specificity of the family system and facilitate planning and control of educational, preventive and intervention processes. The aim of this fragment of research, the results of which are specified in the paper, is to present the level of satisfaction of the academic student respondents with the way their families function and to diagnose the core factors determining a given satisfaction level. In order to show a broader background of the analysis, there are regression models presenting the predictors of satisfaction with the functioning of a family system for the entire study group and as a breakdown into female and male respondents.

The subject of the research was the image of the system within the family of origin as an element of the family identity of the academic youth. Family identity is the element which in a way is inherited (Nikitorowicz, 1995, p. 93) and tamed initially in the course of unintentional participation in family life and then absorbed and internalized through socialization and educational processes (Modrzewski, 2007, pp. 30-35). The image of the family system is in its nature subjective, created by the subject himself, who is both a participant and an observer of the interactions that take place. This corresponds to the constructivist and inclusive way of creating a family image (Biernat, 2014, pp. 183-195). The family map (Levin, 1993), which arises as a result of the visualization of the internal image of the family of the examined unit, shows the relation of this person with other family members and the specificity of its entire structure.

670 people took part in the research. After verifying the completeness of the filled-in survey within the key research categories and rejecting those with signifi- 
cant data gaps, 633 questionnaires of the examined academic youth were qualified for the final analysis. In order to preserve the representativeness of the group of academic youth, the research was conducted on various types of universities: University of Białystok (244 people), Białystok University of Technology (199 people), and Medical University of Białystok (190 people), and various specializations (more feminised, more masculine, and gender-balanced) to maintain a certain proportionality groups of studied women (385 people) and men (248 people).

\section{THE LEVEL OF SATISFACTION OF THE YOUTH UNDER STUDY ON THE FUNCTIONING OF THEIR FAMILY OF ORIGIN SYSTEM}

The key question in my research was the level of satisfaction with the functioning of the families of origin of the young people examined. Satisfaction with family life means the level of satisfaction with the quality of particular areas of its functioning (Felce, 1997, pp. 126-135; Poston et al., 2003, pp. 313-328).

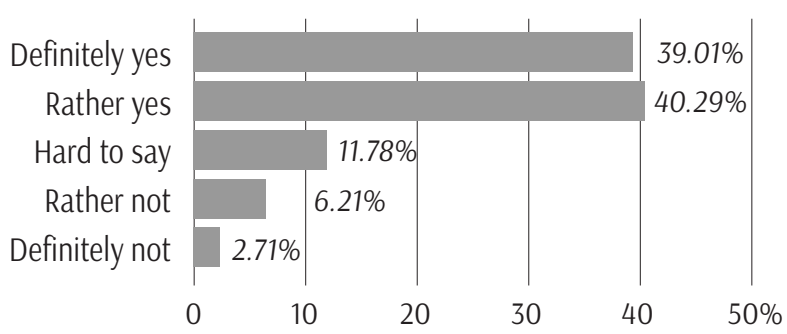

Graph 1. The Level of Satisfaction with the Functioning of the Family of Origin of the Examined Persons

Nearly $80 \%$ of respondents express a decisive or rather satisfying picture of how their families of origin function. Ten times less respondents (less than 9\%) declare a relative or decisive lack of satisfaction with the functioning of their primary families. Nearly $12 \%$ of respondents chose the answer "hard to say". This result shows that despite dynamic social changes in shaping the model of family functioning (Kwak, 2015, pp. 11-26) (e.g., promoting an egalitarian model based on partnership and a compromise crisis resolution method), which is often different from the way of functioning presented by the parents of respondents, their level of satisfaction is high. Such a large declarative level of satisfaction can be caused by many factors. First, it can realistically reflect the state of affairs, be a kind of 
response to positive experiences from childhood and adolescence. Secondly, the studied youth demonstrates a high level of independence and self-decision, which translates into the location of the person in large part already outside the primary system. This may cause a tendency to "polish" the image under consideration resulting from the inserted distance both in time and space (a group of young people studying outside the place of residence of the family of origin). Another source of such declarations may be the fact of some kind of elitism of the examined youth. Students are a group of the most talented people in the space of a particular generation. Often their level of intellectual, emotional and social development is higher in relation to the remaining group of young people and is often the result of the high level of capital represented by their family of origin. One factor is also the fact that by growing in a specific home model, a person tends to rationalize and valorize what he participates in. Besides, the generality of the question, after all, leads to an attempt to analyze the family as a system whose effect is made up of all its members, that is, the respondents, by nature, as well.

\section{A REGRESSION MODEL OF THE LEVEL OF SATISFACTION FROM THE FUNCTIONING OF THE FAMILY OF ORIGIN OF THE ENTIRE STUDY GROUP}

In-depth analysis was performed using hierarchical regression to identify groups of interrelated factors that, taken together, form a model explaining the variability of the selected, main elements of the family history of the respondents. The assumption in the construction of regression models was an attempt to intercorrelate the image of the family system of origin of the respondents in order to show the main predictors of a sense of satisfaction with the functioning of the family of origin of the respondents. It seems interesting to capture what elements of family characteristics make up the global sense of satisfaction with its functioning.

Further, I will present three regression models showing a group of predictors that explain the variability of the sense of satisfaction of the respondents from the way their families of origin function. Considering that sex was a factor strongly differentiating the image of the family of origin system of examined persons, there were also models of regression in separation for the group of studied women and men. In graphic images (Schemes 1-3) presenting a group of positive and negative predictors (depending on proportional and inversely proportional), factors were calculated according to the hierarchy of the odds ratio. This means the probability ratio that the level of satisfaction with the functioning of the family will occur and the probability of its non-occurrence. The results of the exploration of the model of 
the entire studied group were presented in two tables: 1 (presenting the summary of the model) and 2 (presenting the variables of the model).

Table 1. Hierarchical Regression for the Variable "Level of Satisfaction with the Functioning of the Family of Origin" in the Group of Respondents: Model Summary

\begin{tabular}{|c|c|c|c|c|}
\hline \multicolumn{5}{|c|}{ Model-summary } \\
\hline Model & $\mathbf{R}$ & R-squared & Corrected R-squared & Standard error estimate \\
\hline &, $746^{\mathrm{a}}$ &, 556 & $\mathbf{, 5 4 8}$ &, 651 \\
\hline
\end{tabular}

Table 2. Hierarchical Regression for the Variable "Level of Satisfaction with the Functioning of the Family of Origin" in the Group of Respondents: Variables in the Model

\begin{tabular}{|l|c|c|c|c|c|}
\hline \multirow{2}{*}{\multicolumn{1}{|c|}{ Predictors }} & \multicolumn{2}{|c|}{$\begin{array}{c}\text { Standardized } \\
\text { coefficients }\end{array}$} & $\begin{array}{c}\text { Stand- } \\
\text { ardized } \\
\text { factors }\end{array}$ & \multirow{2}{*}{ t } & \multirow{2}{*}{$\begin{array}{c}\text { Signifi- } \\
\text { cance }\end{array}$} \\
\cline { 2 - 5 } & B & $\begin{array}{c}\text { Standard } \\
\text { error }\end{array}$ & Beta & & \\
\hline (Constant) &, 685 &, 220 & & 3,108 &, 002 \\
\hline Quality of relationship with siblings &, 178 &, 041 &, 138 & 4,346 &, 000 \\
\hline Excessive liberal style of leadership &,- 216 &, 090 &,- 072 & $-2,406$ &, 016 \\
\hline $\begin{array}{l}\text { Family as an environment helpful in } \\
\text { shaping life attitudes }\end{array}$ &, 094 &, 039 &, 079 & 2,405 &, 017 \\
\hline $\begin{array}{l}\text { Relationship of parents as role } \\
\text { models }\end{array}$ &, 228 &, 033 &, 322 & 6,850 &, 000 \\
\hline $\begin{array}{l}\text { The way of bringing up children as } \\
\text { a model to follow }\end{array}$ &, 298 &, 035 &, 340 & 8,490 &, 000 \\
\hline Father as authority &, 074 &, 036 &, 100 & 2,074 &, 039 \\
\hline $\begin{array}{l}\text { Presents positive emotions above } \\
\text { all to father }\end{array}$ &, 339 &, 173 &, 058 & 1,953 &, 051 \\
\hline $\begin{array}{l}\text { Presents negative emotions above } \\
\text { all to father }\end{array}$ &, 152 &, 090 &, 055 & 1,682 &, 093 \\
\hline $\begin{array}{l}\text { Presents negative emotions } \\
\text { primarily to siblings }\end{array}$ &, 171 &, 082 &, 065 & 2,099 &, 036 \\
\hline
\end{tabular}

Built on the basis of a study by a group of academic youth, the model explains nearly $55 \%$ of the variance of the level of satisfaction with the functioning of the family of origin. The model creates nine predictors (factors), of which eight explain the probability of a high level of satisfaction in the group of surveyed students, and only one explains the probability of its failure. Scheme 1 shows two groups of predictors, positive and negative, among various elements of the 
declarative image of the family system and sources of shaping life attitudes of the students examined.

LEVEL OF SATISFACTION WITH THE FUNCTIONING OF THE FAMILY OF ORIGIN

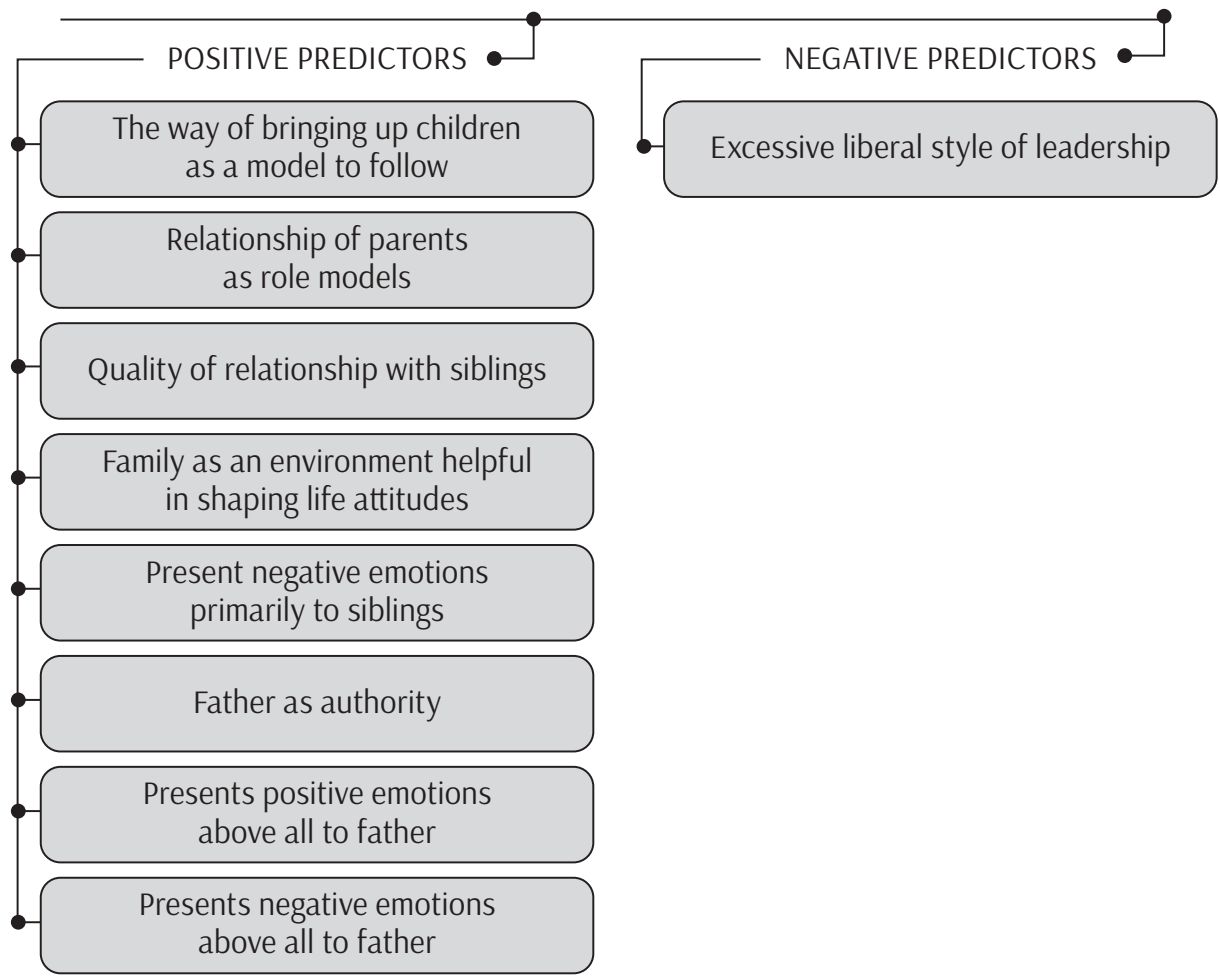

Scheme 1. Predictors of the Level of Satisfaction with the Functioning of the Family of Origin of the Studied Academic Youth

The probability of a high level of satisfaction in the way the family of origin functions, in the light of the presented results of regression analyses, increases the satisfactory relationship between the respondents and their siblings. Emphasizing the role of siblings in shaping a good family climate may indicate that the level of interaction within their generation in the family system is an important factor in the process of building the family identity of the examined academic youth. The importance of siblings in the family system is also evidenced by the predictor conditioning the sense of satisfaction, concerning the expression of negative emotions directed towards siblings. Showing difficult emotions is often an expression of a sense of security in this relationship and trust in the appropriate reception. The likelihood of greater satisfaction of respondents is also increased by the dec- 
laration regarding their great approval for the father and mother's functioning pattern in both marital and parental roles. Interactions between spouses decide about the family climate, the intensity and quality of communication in the family and the level of satisfaction of needs, including, above all, the sense of security (Janicka \& Liberska, 2014, pp. 30-32). The parents in their family roles are, in the light of research results, a factor conducive to the overall assessment of the functioning of the entire system. This would show the most important role of parents in the processes of regulating interaction and creating a suitable family atmosphere conducive to the feeling of satisfaction with its functioning. Three positive predictors regarding the role of the father are worth stressing. The level of satisfaction with the way the family functions is increasing their probability, together with the declaration of acknowledgment of the father's authority and the possibility of presenting him with both positive and negative emotions. Emphasizing the father's high rank, assuming his strong emotional presence in the system, may testify to the respondents' appreciation of his role as a concretized educational character, which is more often implemented in his attitudes (Sosnowski, 2014, pp. 56-73). The importance of family space makes the predictor of the sense of satisfaction, increase of which determines the declaration of high rank of this environment in shaping life attitudes of the respondents. The only predictor that reduces the likelihood of satisfaction from the way the family functions, in the light of the results of student research, was the excessively liberal style of management. This particular style of management causes a break with the natural hierarchical arrangement of relations in the family and the adoption of an excessive level of decision by the generation of children. Such a result may reveal the tendency of overloading observed by the respondents to the responsibility of a generation of children for the proper way of functioning of the system. Emphasizing the role of the father and modeling the role of parents in family roles may indicate a kind of resentment emphasizing the naturalness of the parents-children layout, with a larger decisionmaking level and responsibility left in the hands of father and mother.

\section{THE MODEL OF REGRESSION OF THE LEVEL OF SATISFACTION FROM THE FUNCTIONING OF THE FAMILY OF ORIGIN OF THE ENTIRE GROUP OF MALE RESPONDENTS}

The second of the presented regression models of the level of satisfaction with the functioning of the family of origin was implemented for the group of surveyed men. The results of exploration of this model are presented in Tables 3 and 4. 
Table 3. Hierarchical Regression for the Variable "Level of Satisfaction with the Functioning of the Family of Origin" in the Group of Male Respondents: Model Summary

\begin{tabular}{|c|c|c|c|c|}
\hline \multicolumn{5}{|c|}{ Model-summary } \\
\hline Model & R & R-squared & Corrected R-squared & Standard error estimate \\
\hline &, $823^{f}$ &, 677 & $\mathbf{6 6 1}$ &, 568 \\
\hline
\end{tabular}

Table 4. Hierarchical Regression for the Variable "Level of Satisfaction with the Functioning of the Family of Origin" in the Group of Male Respondents: Variables in the Model

\begin{tabular}{|l|c|c|c|c|c|}
\hline \multicolumn{1}{|c|}{ Predictors } & \multicolumn{2}{|c|}{$\begin{array}{c}\text { Standardized } \\
\text { coefficients }\end{array}$} & $\begin{array}{c}\text { Stand- } \\
\text { ardized } \\
\text { factors }\end{array}$ & t & $\begin{array}{c}\text { Signifi- } \\
\text { cance }\end{array}$ \\
\cline { 2 - 5 } & \multicolumn{2}{|c|}{ B } & $\begin{array}{c}\text { Standard } \\
\text { error }\end{array}$ & Beta & \\
\hline (Constant) &, 937 &, 287 & & 3,269 &, 001 \\
\hline Quality of relationship with siblings &, 318 &, 068 &, 238 & 4,690 &, 000 \\
\hline $\begin{array}{l}\text { In decision-making, is influenced } \\
\text { more by mother's opinion }\end{array}$ &,- 195 &, 106 &,- 085 & $-1,842$ &, 067 \\
\hline $\begin{array}{l}\text { The way of bringing up children as } \\
\text { a model to follow }\end{array}$ &, 423 &, 053 &, 474 & 7,967 & \multirow{2}{*}{, 000} \\
\hline The father as an authority &, 122 &, 044 &, 153 & 2,750 &, 007 \\
\hline $\begin{array}{l}\text { The children's coalition with the } \\
\text { mother in opposition to the father }\end{array}$ &,- 213 &, 110 &,- 093 & $-1,946$ &, 053 \\
\hline $\begin{array}{l}\text { Presents positive emotions above } \\
\text { all to the father }\end{array}$ &, 774 &, 310 &, 112 & 2,495 &, 013 \\
\hline $\begin{array}{l}\text { Presents positive emotions above } \\
\text { all to the siblings }\end{array}$ &,- 772 &, 155 &,- 259 & $-4,994$ &, 000 \\
\hline $\begin{array}{l}\text { Presents positive emotions to all } \\
\text { members of the family to the same } \\
\text { extent }\end{array}$ &,- 247 &, 100 &,- 127 & $-2,467$ &, 015 \\
\hline $\begin{array}{l}\text { Does not present positive emotions } \\
\text { to the family }\end{array}$ &,- 477 &, 211 &,- 102 & $-2,255$ &, 025 \\
\hline
\end{tabular}

The model based on the results obtained by the group of examined men explains more than in the previous model (for the entire study group), as much as $66 \%$ of the variance of the level of satisfaction with the functioning of their families of origin. It is made up of nine predictors, four of which explain the probability of a high level of satisfaction in the group of surveyed students and the other five explain the probability of its non-occurrence. 


\section{LEVEL OF SATISFACTION WITH THE FUNCTIONING OF THE FAMILY OF ORIGIN}

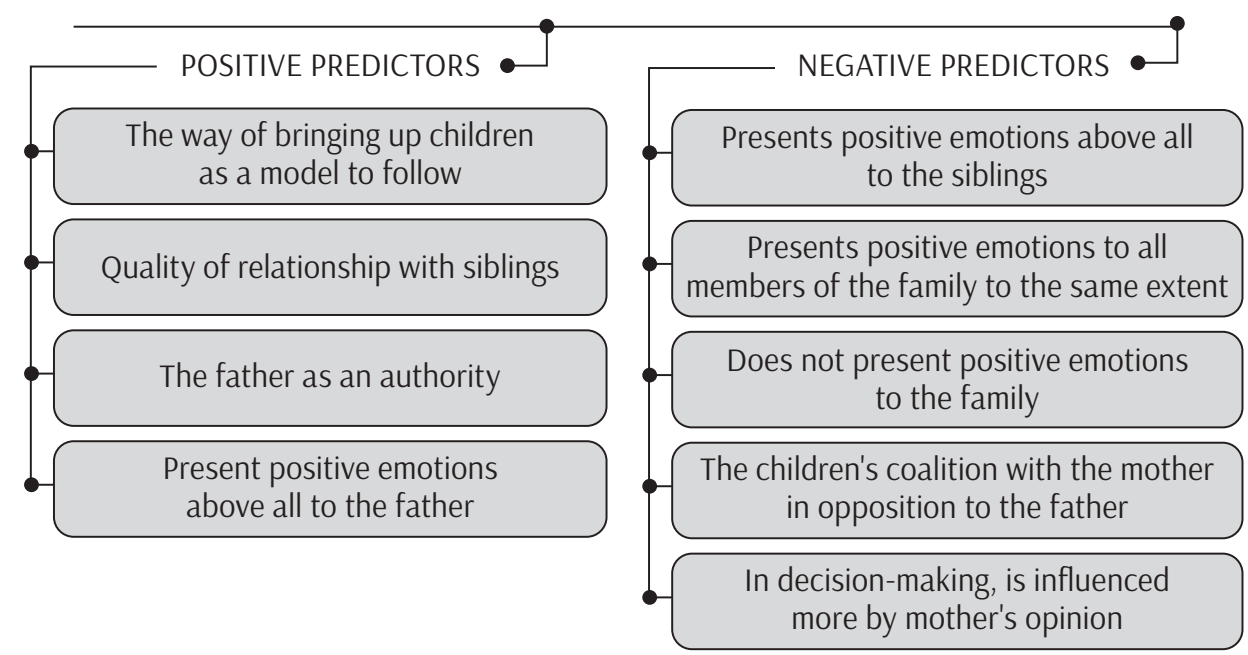

Scheme 2. Predictors of the Level of Satisfaction with the Functioning of the Family of Origin of the Studied Group of Men

In the model built on the basis of the results achieved by the surveyed men, there is a noticeable similarity to that which was implemented for the whole group of students, especially on the level of predictors related to the role of father and siblings. The probability of the appearance of a sense of satisfaction with the way the family of origin functions is greater in case of declarations of satisfying relationship between the surveyed men and their siblings. However, it reduces the likelihood of declaring positive emotions above all to siblings, presenting them all to the same extent or blocking their exposure in the family space. This shows a certain blockage of emotional expression as part of the functioning of the family system in the perception of the male respondents. The probability of greater satisfaction of the respondents from the way the family functions, increases the declaration regarding their great approval for the pattern of their parents' role in parental roles. The generation of parents of the studied youth, according to the social canons that were in force at the time when they created their family, tended to investing in parental space, often more than in the space of their own individual development (Rostowska \& Spryszyńska, 2014, pp. 29-51). The effort put into raising children has been reflected in the importance of this predictor in achieving the participants' sense of satisfaction with the way their families of origin function. The level of satisfaction is also conditioned, in the light of the results of the surveyed men, by the declaration that the father is their authority and that they direct positive emo- 
tions towards him. The high rank of the father seems quite natural in the group of young men under study. It is a model of masculinity and the whole palette of his attitudes becomes a source of behavior modeling, which in effect constructs a sense of his own identity (Bajkowski, 2013, pp. 121-139). At the same time, the contesting nature of the declarations of the surveyed men against the mother's too strong position is noticeable. The probability of the respondents achieving a sense of satisfaction with the way the family of origin is functioning decreases with declarations of a mother-child coalition in their system in opposition to their father. A similar effect can be observed in the declarations of the surveyed males regarding the dominant suggestiveness of the mother, which also reduces the likelihood of a student's sense of satisfaction. This may also result from a strong level of identification of the respondents with the parent of their own sex and reflects the social stereotype of the dominant role of the man in the space of the family system.

\section{THE MODEL OF REGRESSION OF THE LEVEL OF SATISFACTION FROM THE FUNCTIONING OF THE FAMILY OF ORIGIN OF THE ENTIRE GROUP OF FEMALE RESPONDENTS}

The last of the presented regression models of the level of satisfaction with the functioning of the family of origin was implemented for the group of female respondents.

Table 5. Hierarchical Regression for the Variable "Level of Satisfaction with the Functioning of the Family of Origin" in the Group of Female Respondents: Model Summary

\begin{tabular}{|c|c|c|c|c|}
\hline \multicolumn{5}{|c|}{ Model-summary } \\
\hline Model & $\mathbf{R}$ & R-squared & Corrected R-squared & Standard error estimate \\
\hline &, $593^{\mathrm{d}}$ &, 351 & $\mathbf{3 4 0}$ &, 816 \\
\hline
\end{tabular}

The model based on the results of research obtained by a group of women surveyed, explains less in relation to the previous one (for a group of men), because $34 \%$ of the variance of the level of satisfaction with the functioning of their families of origin. However, it is made up of a smaller number of predictors, as only six, out of three, explaining both the probability of a high level of satisfaction in the group of surveyed students, as well as its non-occurrence. 
Table 6. Hierarchical Regression for the Variable "Level of Satisfaction with the Functioning of the Family of Origin" in the Group of Female Respondents: Variables in the Model

\begin{tabular}{|l|c|c|c|c|c|}
\hline \multirow{2}{*}{\multicolumn{1}{|c|}{ Predictors }} & \multicolumn{2}{|c|}{$\begin{array}{c}\text { Standardized } \\
\text { coefficients }\end{array}$} & $\begin{array}{c}\text { Stand- } \\
\text { ardized } \\
\text { factors }\end{array}$ & t & $\begin{array}{c}\text { Signifi- } \\
\text { cance }\end{array}$ \\
\cline { 2 - 6 } & B & $\begin{array}{c}\text { Standard } \\
\text { error }\end{array}$ & Beta & & \\
\hline (Constant) &, 611 &, 432 & & 1,414 &, 158 \\
\hline Quality of relationship with mother &, 305 &, 081 &, 176 & 3,742 &, 000 \\
\hline Quality of relationship with father &, 281 &, 041 &, 323 & 6,848 &, 000 \\
\hline Quality of relationship with siblings &, 231 &, 061 &, 177 & 3,766 &, 000 \\
\hline $\begin{array}{l}\text { Every family member makes decisions } \\
\text { for themselves }\end{array}$ &,- 392 &, 126 &,- 148 & $-3,107$ &, 002 \\
\hline Authoritarian style of leadership &,- 366 &, 140 &,- 119 & $-2,608$ &, 010 \\
\hline Excessive liberal style of management &,- 412 &, 151 &,- 133 & $-2,732$ &, 007 \\
\hline
\end{tabular}

\section{LEVEL OF SATISFACTION WITH THE FUNCTIONING OF THE FAMILY OF ORIGIN}

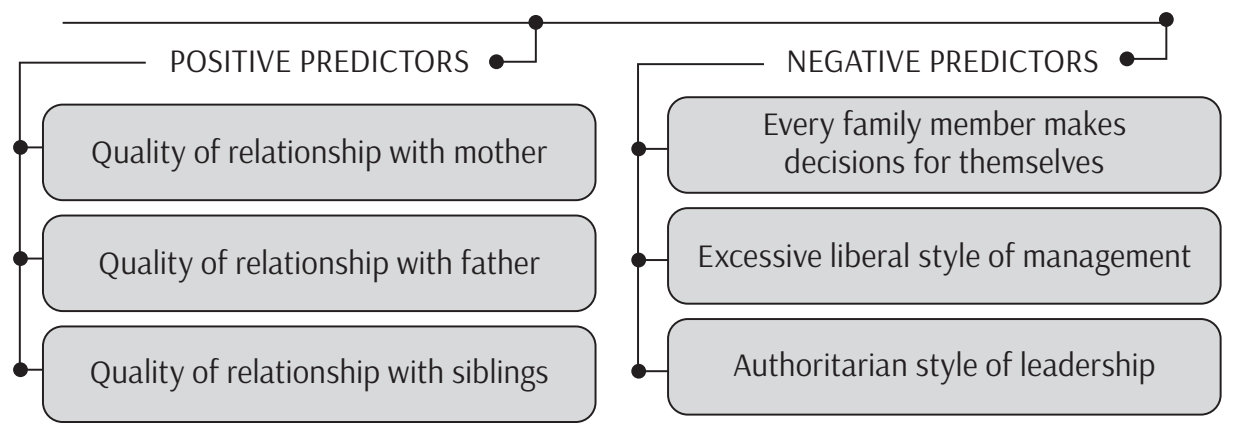

Scheme 3. Predictors of the Level of Satisfaction with the Functioning of the Family of Origin of the Studied Group of Men

The probability of a high level of satisfaction with the functioning of the family of origin, in the light of the presented results of regression analyses, increases the declarative high quality of the relations of the surveyed women with mother, father and siblings, that is, the closest relatives. This confirms the importance of totality as an important principle of the systemic perception of the family (Kaleta, 2011, pp. 141-158]. In order to get to know the functioning of the family, it is necessary to look at all its members as components and the family as a whole. The system is the result of interactions between its elements and has an integral 
structure (Rostowska \& Spryszyńska, 2014, pp. 29-51). From this point of view, it seems important to have a community view on shaping the right family climate, resulting from the declarations of the female respondents. Predictors that reduce the likelihood of satisfaction from the way the family functions, in the light of the results of student research, were two extreme styles of family management, that is, authoritarian and excessively liberal. Both of these management styles interfere with the organizational order that is natural for the family system. It is, similarly to other systems, composed of hierarchically ordered system floors, which have their own level of separate organization but at the same time are related to the higher and lower level (Janicka \& Liberska, 2014). Both the concentration of power in one hand (as it happens in the authoritarian style), as well as the shift of the decision center more towards children (as it takes place in the excessively liberal style) in the perception of the surveyed women adversely affects the level of satisfaction of the way their families of origin were functioning. The predictor, which also reduces the probability of experiencing the sense of satisfaction of the surveyed people, is the distributed level of decision making in the system, consisting in the fact that each of its members makes decisions for themselves. You can refer here to the "structural theory of family" by S. Minuchin (Minuchin, 1974; Grzesiuk, 1987, pp. 33-48] or "theory of family systems" by M. Bowen (Bowen, 1978), which emphasize the role of patterns in the system of mutual references of family members to each other, regulating their behavior and supporting this system as a whole (Kaleta, 2011, pp. 141-158). Like any other social group, the family needs a specific set of norms, principles, and means to maintain its coherence. Excessive autonomy of individual family members, in the light of the results obtained, may affect the appearance of disintegration trends, reducing the sense of satisfaction with the way it functions.

\section{DISCUSSION OF RESULTS}

The results of analyses of models of the sense of satisfaction with the way the family functions, according to the scope of defining satisfaction, are associated with the high level of satisfaction with the quality of many different areas of its functioning (Felce, 1997, pp. 126-135; Poston et al., 2003, pp. 313-328). There are significant differences in the range of predictors building models for the whole group, compared to models built separately for the group of males and females. This indicates a high level of diversity in the perception of the family of origin system among the surveyed students. The main differences outlined are the emphasis 
on the community character of intra-family relations in the image of predictors conducive to achieving satisfaction from the functioning of the family of origin of the surveyed women. At the same time, in this group of respondents, the negative influence of the extreme styles of management (authoritarian and excessively liberal) on the level of achieved satisfaction is noticeable. In the group of studied men, however, one can observe the important role of the father in regulating the emotional climate of the family, while simultaneously predicting the negative strong position of the mother in the system. In this group, the tendency to block emotional expression directed to all system members and the negative impact of coalition systems is also noticeable.

Analyses of the presented models regarding the level of satisfaction from the way the family functions show the image of academic youth, who in their life orientations values the family very much, as the basic reference point in the construction of their own identity. There is a visible focus on the community nature of its functioning, the quality of the relations of individual members of the system and the possibility of participating in the rules developed in the family. The family identity that develops with said rules is a kind of negotiated creation of the family traditions recognized by them, with simultaneous outlined tendencies of deconstruction of the existing model ways of capturing the family structure, in favor of seeking a different view, which is a kind of adaptation of the system to dynamically changing socio-cultural conditions. In the light of the results of model analyses, there was also a need for exposure and exploration on the emotional level in the space of the family environment, which may be a challenge for the construction of methodical support strategies for family systems.

\section{References}

Antonovsky, A. (1995). Rozwikłanie tajemnicy zdrowia. Jak radzić sobie ze stresem i nie zachorować. Warszawa: Fundacja IPN.

Bajkowski, T. (2013). Rola rodziców w kształtowaniu obrazu kobiecości i męskości w percepcji współczesnej młodzieży akademickiej. In: J. Brągiel, P.E. Kaniok, \& A. Kurcz (Eds.), Rodzicielstwo w kontekście wychowania i edukacji (pp. 121-139). Opole: Wyd. UO.

Bajkowski, T. (2018). U źródeł tożsamości rodzinnej. System rodzinny w percepcji młodzieży akademickiej. Warszawa: Wyd. Naukowe Scholar.

Barbaro, B. (Ed.). (1999). Wprowadzenie do systemowego rozumienia rodziny. Kraków: Wyd. UJ.

Biernat, T. (2014). Czy istnieje rodzina ponowoczesna? Pedagogia Christiana, 34(2), pp. 183-196.

Bowen, M. (1978). Family Therapy in Clinical Practice. New York: Jason Aronson Inc. 
Felce, D. (1997). Defining and Applying the Concept of Quality of Life. Journal of Intellectual Disability Research, 41, pp. 125-136. DOI: 10.1111/j.1365-2788.1997.tb00689.x.

Grzesiuk, L. (1987). Strukturalna terapia rodziny w ujęciu Minuchina. Nowiny Psychologiczne, 1, pp. 33-48.

Janicka, I., \& Liberska, H. (Eds.). (2014). Psychologia rodziny. Warszawa: Wyd. Naukowe PWN.

Kaleta, K. (2011). Rodzinne uwarunkowania społecznego funkcjonowania jednostek w świetle teorii Minuchina i Bowena. Rocznik Psychologiczny, 14(2), pp. 141-158.

Kwak, A. (2015). Współczesna rodzina - czy tylko problem struktury zewnętrznej? In: I. Taranowicz, \& S. Grotowska (Eds.), Rodzina wobec wyzwań współczesności. Wybrane problemy (pp. 11-26). Wrocław: Oficyna Wyd. Arboretum.

Levin, I. (1993). Family as Mapped Realities. Journal of Family Issues, 14(1), pp. 82-91.

Minuchin, S. (1974). Families and Family Therapy. Cambridge: Harvard University Press.

Modrzewski, J. (2007). Socjalizacja i uczestnictwo społeczne. Studium socjopedagogiczne (2 ${ }^{\text {nd }}$ Ed.). Poznań: Wyd. Naukowe UAM.

Nikitorowicz, J. (1995). Pogranicze. Tożsamość. Edukacja międzykulturowa. Białystok: Wyd. Trans Humana.

Papini, D. (1994). Family Interventions. In: S. Archer (Ed.), Interventions for Adolescent Identity Development (pp. 47-61). London: Sage Publications.

Poston, D., Turnbull, A.P., Park, J., Mannan, H., Marquis, J., \& Wang, M. (2003). Family Quality of Life: A Qualitative Inquiry. Mental Retardation, 41(5), pp. 313-328.

Rostowska, T., \& Spryszyńska, M. (2014). Małżeństwo a funkcjonowanie rodziny. Rocznik Pedagogiczny, 42(3), pp. 29-51.

Rostowski, J. (2003). Style przywiązania a kształtowanie się związków interpersonalnych w rodzinie. In: I. Janicka, \& T. Rostowska (Eds.), Psychologia w służbie rodziny (pp. 19-31). Łódź: Wyd. UŁ.

Rostowski, J. (2005). Rodzinne uwarunkowania kształtowania się tożsamości osobowej człowieka. Psychologia Rozwojowa, 10(2), pp. 13-21.

Sosnowski, T. (2014). Pedagogiczny model ojcostwa - konstrukt teoretyczny. Dziecko krzywdzone. Teoria, badania, profilaktyka, 13(3), pp. 56-73.

Werner, I. (2013). Poczucie rodzinnej koherencji - pojęcie oraz implikacje psychopedagogiczne. In: M. Piorunek, J. Kozielska, \& A. Skowrońska-Pućka (Eds.), Rodzina - Młodzież - Dziecko. Szkice z teorii i praktyki pomocy psychopedagogicznej i socjalnej (pp. 73-84). Poznań: Wyd. Naukowe UAM. 